\title{
PENgobatan tradisional DI Kalangan ANaK-ANaK (STUDI KASUS DI KECAMATAN SOREANG)
}

\author{
CHILDREN TRADITIONAL MEDICINE \\ (A CASE STUDY IN SOREANG REGENCY)
}

\author{
Ria Intani T. \\ Balai Pelestarian Nilai Budaya Bandung \\ Jl. Cinambo No. 136 Ujungberung-Bandung \\ e-mail: ria_intani@yahoo.com
}

\begin{abstract}
Abstrak
Pengobatan tradisional merupakan satu sistem pengobatan yang tata caranya berdasarkan pengetahuan yang didapat secara turun temurun. Pengobatan tradisional tidak saja diperuntukkan guna pengobatan suatu penyakit, melainkan pula mengobati kebiasaan buruk pada anak-anak yang di antaranya adalah menghisap jari dan ketergantungan pada dot, Asi, dan ibunya. Sebagian orang mendapatkan solusinya melalui seorang pengobat tradisional. Pertanyaannya adalah bagaimanakah profil pengobat yang bersangkutan, bagaimana pengetahuan pengobatan tersebut didapat, bagaimana tata cara pengobatannya, dan mengapa orang memercayai pengobatan tersebut. Pengobatan tradisional, dengan kondisinya yang masih terus "hidup", tak dapat dinafikan merupakan kekayaan budaya yang memberi kontribusi di bidang kesehatan. Oleh karena itu bidang pengobatan tradisional perlu mendapatkan perhatian, salah satunya dengan mengkajinya melalui kegiatan penelitian. Tipe penelitian yang digunakan adalah deskriptif kualitatif. Dengan demikian, dalam pengambilan datanya menggunakan teknik wawancara dan observasi. Adapun teknik analisis data yang dilakukan adalah analisis kualitatif yang bersifat deskriptif interpretatif. Sampai saat ini pengobatan ini masih berlangsung dengan jumlah konsumen yang fluktuatif dan dari kalangan yang beragam.
\end{abstract}

Kata kunci: pengobatan tradisional, kebiasaan buruk, anak-anak.

\begin{abstract}
Traditional medicine is a knowledge-based operation system of medicine which is gained from generation to generation. Traditional medicine is not only intended to the treatment of a disease, but also to cure the children bad habits, such as licking their fingers and the addiction ofmilk bottle, breast milk, and her mother. Some people get this solution through a traditional healer.The question is how the healers profile is concerned, how medical knowledge is obtained, how the procedures of treatment are, and why people believe in such treatment. Traditional medicine, remains in "alive"condition, cannot be denied asa cultural wealth that contributes in the health field. Hence the field of traditional medicine needs to be concerned, such as by studying through research activities. This type of research is descriptive qualitative. Thus, in collecting the data, interview and observation techniques are employed. The data analysis technique is interpretative descriptive of qualitative analysis. Until now, this treatment is still in progress with a number ofvolatile and different consumers.
\end{abstract}

Keywords: Traditional medicine, Bad Habits, children. 


\section{A. PENDAHULUAN}

Ada banyak pengertian tentang kebudayaan, satu di antaranya adalah yang didefinisikan oleh Andreas Eppink bahwa kebudayaan mengandung keseluruhan pengertian nilai sosial, norma sosial, ilmu pengetahuan, serta keseluruhan struktur sosial , religius, tata nilai, intelektualitas, dan artistis dan seni pada masyarakat (Saebani, 2012: 162). Tidak berbeda dengan Eppink, E. B. Tylor memberikan definisi tentang kebudayaan yakni merupakan keseluruhan yang kompleks, yang di dalamnya terkandung pengetahuan, kepercayaan, kesenian, moral, hukum, adat istiadat, dan kemampuan lain yang didapat seseorang sebagai anggota masyarakat (Saebani, 2012: 162). Kedua definisi tersebut menyinggung terdapatnya ilmu pengetahuan di dalamnya. Koentjaraningrat, meskipun hanya mendefinisikan kebudayaan sebagai hasil cipta, karsa, dan rasa manusia (Saebani, 2012: 161), namun demikian menurut Koentjaraningrat, salah satu unsur kebudayaan adalah juga ilmu pengetahuan (Saebani, 2012: 163).

Kebudayaan berkaitan dengan sistem ilmu pengetahuan. Ilmu merupakan akumulasi dari pengetahuan. Pengetahuan itu sendiri menurut Juhana S. Pradja memiliki tiga kriteria, yakni: adanya suatu sistem gagasan dalam pikiran; Persesuaian antara gagasan dengan benda-benda yang sebenarnya; Adanya keyakinan tentang persesuaian itu (Saebani, 2012: 179). Hal yang termasuk ke dalam ilmu pengetahuan salah satunya adalah sistem pengobatan. Dan, apabila dikaitkan dengan ilmu pengetahuan tentang pengobatan yang sifatnya turun temurun dari satu generasi ke generasi berikutnya maka ilmu pengetahuan yang dimaksud adalah sistem pengobatan tradisional ${ }^{1}$.

Dalam Keputusan Menteri Kesehatan Nomor 1076 Tahun 2003 Pasal 1 (1) pengertian pengobatan tradisional adalah: "pengobatan dan/atau perawatan dengan cara, obat dan pengobatnya yang mengacu pada pengalaman, keterampilan turun temurun, dan/atau pendidikan/pelatihan, dan diterapkan sesuai dengan norma yang berlaku dalam masyarakat (Yasin, 2013: 36-37).

Dewasa ini, meskipun zaman sudah serba tek (baca: teknologi), demikian halnya di bidang pengobatan, namun sistem pengobatan tradisional belum ditinggalkan. Pengobatan tradisional masih berlangsung di sebagian kalangan masyarakat, di antaranya di daerah yang jauh dari fasilitas kesehatan, di daerah yang masih kaya akan tanaman obat, pada mereka yang secara ekonomi kurang mampu, dan pada mereka yang memercayai keampuhan dari pengobatan tradisional, terlepas mampu atau kurang mampu secara ekonomi. Dalam praktik sehari-hari, acapkali pengobatan tradisional berjalan berdampingan dengan pengobatan modern.

Keberlangsungan pengobatan tradisional tidak dapat diabaikan mengingat pengalaman menunjukkan bahwa sebagian penyakit yang dialami warga masyarakat dapat disembuhkan dengan cara ini. Apalagi keberadaan pengobatan tradisional semakin mendapat pengakuan di bidang kesehatan, menyusul adanya hasil riset yang menunjukkan berbagai tumbuhan bermanfaat bagi kesehatan dan kecantikan (Yanti Nisfiyanti, 2012: 126). Departemen Kesehatan melalui Undang-Undang No. 23 tahun 1992 tentang kesehatan mengakui keberadaan pengobatan tradisional dan obat tradisional sebagai bagian yang tidak dapat diabaikan dalam pelayanan kesehatan (Dermawan, 2013: 51).

Bedanya dengan pengobatan yang ditangani oleh tenaga medis, dalam pengobatan yang sifatnya tradisional, hubungan antara pasien dengan pengobatnya seringkali lebih dekat. Pasien menganggap pengobat sebagai seseorang 
yang mampu memahami masalah dalam konteks kultural, berbicara dengan bahasa yang sama, dan memiliki pandangan yang sama tentang dunia (Dermawan, 2013: 52).

Menurut Kementerian Kesehatan Republik Indonesia melalui Badan Penelitian dan Pengembangan Kesehatan, pengobat tradisional adalah orang yang mengetahui tentang tumbuhan obat, meramu obat, dan yang melakukan praktik pengobatan tradisional (Dermawan, 2013: 52).

Menurut WHO, pengobatan tradisional adalah jumlah total pengetahuan, keterampilan, dan praktikpraktik yang berdasarkan pada teori-teori, keyakinan, dan pengalaman masyarakat yang mempunyai adat budaya yang berbeda, baik dijelaskan atau tidak, digunakan dalam pemeliharaan kesehatan serta dalam pencegahan, diagnosa, perbaikan atau pengobatan penyakit secara fisik dan juga mental (Dermawan, 2013: 52).

Pengobatan tradisional, dengan kondisinya yang masih terus "hidup", tak dapat dinafikan merupakan kekayaan budaya yang memberi kontribusi di bidang kesehatan. Oleh karena itu bidang pengobatan tradisional harus mendapatkan perhatian, salah satunya dengan mengkajinya melalui kegiatan penelitian.

Pengobat/ pengobatan tradisional yang dimaksudkan dalam penelitian ini dibatasi dalam hal menyembuhkan atau menghilangkan kebiasaan buruk pada anak-anak. Dengan demikian meskipun pengobat yang dimaksud dapat pula mengobati atau menghilangkan kebiasaan buruk pada orang dewasa, akan diabaikan. Penelitian dibatasi pada pengobatan untuk kebiasaan menghisap jari dan ketergantungan pada dot, Asi, dan ketergantungan pada sang ibu (anak tidak mau lepas dari ibunya).

Terkait dengan penelitian ini, yang menjadi pertanyaan adalah seperti apakah profil dari pengobat tradisional tersebut, dari mana pengetahuan pengobatan tersebut diperoleh, bagaimana tata cara pengobatannya, dan mengapa orang memercayai pengobatan tersebut.

Teori yang digunakan dalam penelitian ini adalah Teori Aksi dari Talcott Parsons ${ }^{1}$. Dalam The Structure of Social Action, Parsons menggambarkan aksi (action) sebagai berikut:

"Aksi sebagai tingkah laku voluntaristik yang mencakup beberapa elemen pokok: (i) Aktor sebagai individu yang aktif. (ii) Aktor memiliki tujuan yang ingin dicapai. (iii) Aktor dihadapkan pada pilihan beragam cara yang dapat ditempuh untuk mencapai tujuan. (iv) Terdapat beragam kondisi dan situasi yang bisa memengaruhi aktor dalam memilih cara untuk mencapai tujuan. (v) Penentuan tujuan yang diinginkan dan cara untuk mencapainya, senantiasa berpedoman pada nilai-nilai, normanorma, dan ide-ide tertentu yang ada dalam lingkungan sosial di mana aktor berada. (vi) Tindakan ataupun pengambilan keputusan untuk bertindak dengan cara tertentu, merupakan hasil dari pertimbangan aktor atas segala sistem situasi yang ia hadapi (nilai, norma, kondisi, dan situasi)" (Bungin, 2009: 35-36).

Pada karyanya yang lain, Parsons mengkonstatasi bahwa setiap tindakan selalu melibatkan empat dimensi pokok, yakni dimensi kultural, sosial, psikologis, dan biologis. Berikut penjabarannya:

"Dimensi kultural berkaitan dengan nilai-nilai yang menjadi orientasi tindakan seseorang karena dianggap baik. Dimensi sosial dari tindakan

\footnotetext{
1 Teori Aksi dari Talcott Parsons menjelaskan bahwa seorang individu tak mungkin lepas dari ikatan-ikatan struktur sosial di mana ia berada. Namun demikian seorang individu memiliki kemampuan untuk memilih berbagai alternatif tindakan secara aktif, kreatif, dan evaluatif yang memungkinkan tercapainya tujuan khas yang ia inginkan (Bungin, 2009: 35).
} 
berkaitan dengan keberadaan norma bersama yang menjadi pedoman tingkah laku seseorang dalam kelompok. Dimensi psikologis berkaitan dengan tujuan-tujuan tertentu yang secara rasional dipilih oleh seseorang, termasuk pemilihan cara, alat, serta teknik untuk mencapai tujuan tersebut. Sedangkan dimensi biologis berkaitan dengan kondisi-kondisi situasional dalam diri seseorang yang membatasi atau memberi peluang untuk melakukan tindakan tertentu" (Bungin, 2009: 36).

Analog dari skema dasar Teori Aksi tersebut dapat dikatakan bahwa tindakan seseorang terkait dengan beberapa variabel berikut:

"Pertama, variabel nilai dan norma. Pada asas nilai dan norma, tindakan seseorang selalu dikondisikan oleh nilai dan norma bersama di mana ia berada. Hal itu disebabkan karena seorang individu pada dasarnya bereksistensi sosial........ Kedua, variabel tujuan, setiap tindakan memiliki tujuan tertentu. Kepada tujuan itulah tindakan seorang individu diarahkan. Tujuan yang hendak dicapai akan menentukan bagaimana seseorang memilih cara, alat, strategi yang akan ditempuh. Walaupun seseorang tidak bebas total karena adanya ikatan-ikatan struktur dan norma-norma sosial yang berlaku, namun ia memiliki kemampuan untuk memilih berbagai alternatif tindakan secara aktif, kreatif, dan evaluatif yang memungkinkan tercapainya tujuan yang dituju. Ketiga, variabel sumber daya. Untuk mencapai tujuan yang dikehendaki, seorang membutuhkan sarana pendukung, baik berupa kemampuan ekonomi maupun kemampuan nonekonomi. Faktor sumber daya ini berperan sebagai kekuatan adaptif bagi seseorang, baik dalam menentukan cara, sarana, serta teknik mencapai tujuan, maupun dalam mempertimbangkan nilai-nilai dan norma-norma bersama yang harus ia patuhi......." (Bungin, 2009: 36-37).

Penelitian ini menggunakan beberapa konsep seperti:

- Obat, dalam KBBI (2013: 974), diartikan bahan untuk mengurangi, menghilangkan penyakit, menyembuhkan seseorang dari penyakit.

- Obat kampung, dalam KBBI (2013: 974), diartikan sebagai obat dari tumbuh-tumbuhan dan sebagainya yang diramu sendiri atau oleh dukun (bukan dari apotek atau dari pabrik farmasi).

- Obat luar, dalam KBBI (2013: 974), diartikan sebagai obat yang dioleskan atau diteteskan untuk menyembuhkan penyakit luar (seperti kudis, panu) dan bukan untuk diminum atau ditelan.

- Obat tradisional, dalam KBBI (2013: 974), diartikan sebagai obat yang diramu dari berbagai macam akar, kulit pohon, batang, bunga, buah, dan daun untuk berbagai macam penyakit; obat kampung.

- Pengobatan, dalam KBBI (2013: 974), diartikan proses, perbuatan mengobati.

- Medis, dalam KBBI (2013: 975), diartikan sebagai berhubungan dengan kedokteran.

- Tradisional, dalam KBBI (2013: 1483) diartikan sebagai menurut tradisi.

- Modern, dalam KBBI (2013: 924), diartikan sebagai terbaru, mutakhir. Sikap dan cara berpikir serta cara bertindak sesuai dengan tuntutan zaman.

\section{B. METODE PENELITIAN}

Tipe penelitian yang digunakan berkenaan dengan penelitian pengobatan tradisional ini adalah deskriptif kualitatif. Adapun teknik analisis data yang dilakukan adalah analisis kualitatif yang bersifat deskriptif interpretatif.

Prosedur yang digunakan dalam analisis mencakup tahapan-tahapan 
klasifikasi, interpretasi, dan penarikan kesimpulan. Alurnya adalah setelah data terkumpul, dilakukan seleksi terlebih dahulu berdasarkan realibilitasnya. Data yang lolos seleksi selanjutnya diinterpretasikan untuk selanjutnya dilakukan penarikan kesimpulan sebagai jawaban atas permasalahan yang diajukan dalam penelitian (Wirata, 2012: 79).

Wawancara dilakukan terhadap informan kunci, yakni pengobat tradisional yang saat ini masih melakukan pengobatan dan beberapa informan, yakni orang yang pada saat itu sedang berobat. Wawancara dilakukan dengan berpedoman pada pedoman wawancara yang telah dipersiapkan sebelumnya agar penelitian tetap fokus atau terarah.

Tahapan dari penelitian diawali dengan mengidentifikasi masalah, merumuskan permasalahan, studi pustaka, membuat rancangan penelitian (pedoman wawancara), penggalian data lapangan, pengolahan data, dan penyimpulan hasil penelitian.

\section{HASIL DAN BAHASAN}

\section{Kebiasaan Buruk pada Anak}

Fase manusia dimulai dari fase bayi, anak-anak, remaja, dewasa, dan kemudian tua. Di antara semua fase, fase anak-anak, terutama mereka yang tergolong balita (dibawah usia lima tahun), adalah fase yang dianggap paling rentan terhadap penyakit. Hal ini dapat dipahami oleh karena mereka belum memahami masalah kesehatan khususnya dan kebersihan pada umumnya. Wajar apabila kemudian balita memiliki kebiasaan yang kontra dengan masalah kesehatan.

Beberapa kebiasaan anak balita yang tidak baik atau kontra dengan masalah kesehatan di antaranya adalah kebiasaan menghisap jari dan ketergantungan pada dot, Asi, dan ketergantungan pada ibunya.

Menghisap jari yakni, salah satu, dua, atau bahkan empat dari kelima jarinya dimasukkan ke dalam mulut. Jari dimasukkan ke dalam mulut sampai kurang lebih satu sampai dua ruas kemudian diisap-isap. Acapkali, begitu asyiknya jari dihisap hingga menimbulkan bunyi dan jari tangannya basah. Adapula bukan jari yang diisap, melainkan ibu jari alias jempol.

Menghisap jari biasa dilakukan manakala anak tidak sedang makan dan minum. Menghisap jari, bilamana sudah menjadi kebiasaan, menjadi seperti suatu penyakit. Istilah penyakit dilontarkan oleh ibu yang merasa putus asa dengan kebiasaan anaknya menghisap jari yang tak kunjung hilang.

Berdasarkan informasi, anak dengan kebiasaan buruk seperti menghisap jari lebih beresiko untuk memiliki gigi tonggos. Sebabnya, pada saat anak melakukan gerakan menghisap, jari akan memberi tekanan pada langit-langit mulut serta menyebabkan gigi terdorong ke depan. Tingkat keparahannya sangat bergantung pada berapa lama kebiasaan dilakukan setiap harinya, posisi jari, dan jangka waktunya dalam arti apakah dilakukan secara terus menerus atau tidak. ${ }^{2}$

Ketergantungan pada dot yakni, anak dengan usia lebih dari 2 tahun masih minum susu dengan menggunakan botol ber-dot.

"Dot atau empeng memang menjadi alat yang biasa digunakan dan terbukti ampuh untuk menenangkan si kecil saat rewel atau saat ingin tidur. Namun akan kewalahan untuk menghilangkan kebiasaanya ketika sudah menjadi ketergantungan. Jika dotnya di ambil, seringkali anak malah rewel dan menangis sejadinya. Kebanyakan kasus yang terjadi, anak masih suka dot atau ngempeng sampai usia 3-5 tahun bahkan lebih. Padahal, kebiasaan mengempeng bagi anak dapat memberikan efek

${ }^{2}$ https://ireinenorma.wordpress.com/about/ Kebiasaan Buruk pada Anak oleh Irene Norma. Diakses pukul 20.30 WIB. 
buruk untuk pertumbuhan gigi anak." 3

Selain itu, didapat informasi bahwa ketergantungan pada dot di antaranya dapat berakibat: meningkatkan risiko terkena diare karena sangat sulit untuk mempertahankan dot dalam keadaan bersih selama seharian; kerusakan gigi, yaitu gigi tonggos. Hal ini terjadi jika dot diberikan kepada anak yang sudah tumbuh giginya, apalagi jika digunakan dalam jangka waktu yang lama; Infeksi telinga tengah, terutama jika penggunaannya pada anak yang berusia lebih dari 10 bulan. Hal ini disebabkan karena penggunaan dot meningkatkan produksi air liur, meningkatkan pertumbuhan jamur, dan memodifikasi tipe bakteri yang ada di mulut, kemudian gerakan menghisap yang konstan memicu perpindahan kumankuman tersebut ke dalam telinga tengah. ${ }^{4}$

Ketergantungan pada Asi yakni, anak dengan usia di atas 2 tahun masih menetek pada ibunya. Adapun ketergantungan pada ibu yakni, anak selalu menempel pada ibunya, tidak mau lepas dari ibunya, "tidak mau" sama orang lain.

Meskipun ketergantungan pada Asi dibatasi usia maksimal 2 tahun, namun oleh karena beberapa faktor, acapkali batasan usia tersebut diperpendek oleh ibunya. Salah satu faktornya adalah karena si ibu ingin bekerja di luar rumah. Sebagai contoh, pada saat dilakukan pengambilan data di lokasi pengobatan, datang seorang ibu yang ingin menghentikan Asinya pada saat anaknya berusia 1 tahun 2 bulan.

${ }^{3}$ http:/www.wishingbaby.com/manfaat-asieksklusif/. Manfaat Asi Eksklusif oleh Wishingbaby. Diakses 22 Agustus 2015, pukul 19.33 WIB.

${ }^{4}$ http://www.tanyadok.com/anak/dot-atauempeng-bergunakah-untuk-bayi. Diakses pukul 20.10 WIB.
Permintaan pasien tersebut dikabulkan oleh si pengobat dengan pertimbangan si ibu telah menjalani Asi eksklusif 6 bulan sesuai anjuran pemerintah, dalam hal ini yang menangani masalah kesehatan ibu dan anak. Selain itu, pengobat pernah mendapatkan informasi dari seorang bidan bahwasanya kualitas atau nutrisi atau vitamin dari Asi setelah 6 bulan sudah berkurang.

Tentang pentingnya pemberian Asi diulas sebagai berikut:

"Berapa lama seorang ibu akan menyusui adalah keputusan pribadi untuk setiap keluarga. Organisasi Kesehatan Dunia, WHO www.unicef.org merekomendasikan Asi eksklusif selama 6 bulan dan kemudian dilanjutkan Asi dikombinasikan dengan makanan padat selama 12-24 bulan atau selama ibu dan bayi menginginkanya. Menurut WHO, menyusui bayi selama 9 bulan bermanfaat untuk perkembangan otak dan tubuh bayi. Sedangkan menyusui bayi selama 1-2 tahun akan memiliki sistem kekebalan tubuh yang kuat. ${ }^{5}$

Asi membantu bayi mengembangkan sistem kekebalan tubuh dan melindungi dari alergi. Asi di antaranya mengandung zat mineral, vitamin, lemak, dan asam amino.

\section{Pengetahuan Pengobatan}

Atas kebiasaan-kebiasaan buruk yang sering terjadi pada anak-anak balita, ada berbagai upaya yang dicoba dilakukan oleh ibu-ibu untuk menghilangkannya.

Beberapa upaya yang terdengar dilakukan dengan membubuhkan obat merah pada jari yang biasa dihisap.

\footnotetext{
${ }^{5}$ http:/www.wishingbaby.com/manfaat-asieksklusif/. Manfaat Asi Eksklusif oleh Wishingbaby. Diakses 22 Agustus 2015, pukul 19.33 WIB.
} 
Tujuannya, agar manakala anak akan menghisap jari, ia menjadi takut karena jarinya berwarna merah lalu mengurungkannya. Ada lagi yang mengoleskan sari daun bratawali ke jari si anak. Sari tersebut diambil dari daun bratawali yang digerus secara kasar hingga mengeluarkan air. Daun bratawali berasa pahit hingga diharapkan setelah si anak menghisap jari ia akan merasakan pahit pada jarinya dan kemudian menjadi jera. Cara tersebut dilakukan pula untuk dot dan Asi. Caranya, dot dan puting si ibu diolesi obat merah atau sari daun bratawali.

Pengobatan dengan cara demikian tidak selamanya dianggap manjur. Ada ibu yang masih mengeluhkan kebiasaan anaknya menghisap jari, ketergantungan minum susu dengan botol ber-dot, atau tidak bisa lepas dari Asi.

Atas kegagalan pengobatannya itu, berbagai upaya dilakukan, berbagai kiat dicoba, dan berbagai informasi dicari. Bagi orang yang akrab dengan teknologi, informasi dicari pula melalui jaringan internet tentang solusi menghentikan salah satu kebiasaan buruk tersebut. Di sana di antaranya didapatkan tiga kiat untuk menghentikan kebiasaan anak menggunakan dot, yakni: memotong bagian ujung dot, mengganti kebiasaan menggunakan dot dengan hal lain, atau batasi penggunaan dot secara bertahap. ${ }^{6}$

Selain upaya dan informasi di atas, didapatkanlah kemudian satu informasi tentang seseorang yang mampu mengobati kebiasaan-kebiasaan buruk pada anak dengan tata cara tradisional. Berdasarkan pengalaman orang lain akan keberhasilan pengobatan dimaksud, kemudian informasi terakhir ini menjadi pilihan dalam pengobatan. Lokasi pengobatan berada di Kecamatan Soreang.

\section{Gambaran Umum Kecamatan Soreang}

${ }^{6}$ http://nutrisianaksehat.blogspot.com/2015/05/ cara-agar-anak-berhenti-ngempengngedot.html
Soreang merupakan ibu kota Kabupaten Bandung. Kecamatan Soreang berada lebih kurang 18 kilometer dari Kota Bandung dengan luas lebih kurang 2.550,68 hektar. Tepatnya di sebelah selatan Kota Bandung. Kecamatan Soreang memiliki batas wilayah sebagai berikut:

- sebelah utara : berbatasan dengan Kabupaten Bandung Barat, Kota Bandung, Kota Cimahi, dan Kabupaten Sumedang,

- sebelah selatan : berbatasan dengan Kabupaten Garut dan Cianjur,

- sebelah barat : berbatasan dengan Kabupaten Cianjur,

- sebelah timur : berbatasan dengan Kabupaten Garut ${ }^{7}$.

Bandung-Soreang dapat ditempuh dengan menggunakan angkutan umum jurusan Soreang dari Tegallega, Terminal Leuwi Panjang, atau sub Terminal Kebon Kelapa. Apabila dengan menggunakan kendaraan pribadi beroda empat, memakan waktu lebih kurang 1,5 jam. Lamanya perjalanan lebih disebabkan kemacetan di sepanjang ruas jalan menuju Soreang.

\section{Profil Pengobat}

Tersebutlah seorang ibu. Sehari-hari, ia membuka warung nasi dengan menu kojonya sate dan gule. Sambil berjualan nasi, ia membuka praktik pengobatan, tepatnya menghilangkan kebiasaankebiasaan buruk pada anak-anak. Tempat praktik di Pasar Soreang, yang secara administratif termasuk ke dalam Kelurahan Soreang, Kecamatan Soreang, Kabupaten Bandung.

Awalnya, praktik pengobatan dilakukan oleh orang tuanya yang akrab di sapa "abah", Abah Gogo. Adapula yang menyapanya dengan "emak", Mak Gogo. Ia hanya sesekali membantu atau menggantikan ayahnya manakala ayahnya akan beristirahat terlebih dulu di rumahnya. Di sela-sela kesibukan menjual nasi itulah ia membantu ayahnya.

${ }^{7}$ https://id.wikipedia.org/wiki/Soreang,_Bandun g. Diakses 19 Agustus 2015, 14.26 WIB. 
Manakala ayahnya meninggal pada sekitar tiga tahun yang lalu, mutlak pengobatan dilakukan olehnya seorang diri.

Menurutnya, dari ke-13 anak Abah, semuanya mampu melakukan pengobatan. Hanya saja hanya dia yang memiliki minat jadi pengobat. Pengetahuan yang ia terima dari ayahnya, selain diperoleh dari melihat ayahnya pada saat melakukan pengobatan, juga mendapatkan ilmu secara khusus dari ayahnya.

Secara umum, orang yang pintar mengobati sering dijuluki sebagai "orang pintar"/ dukun ${ }^{8}$ dan sebagainya. Meskipun demikian, dalam hal pengobat yang dimaksud dalam penelitian ini, nyaris tidak pernah terdengar dijuluki sebagai dukun. Pada umumnya orang menjuluki sebagai orang pinter (orang pintar).

Bukan tidak mungkin orang ("pasien") tidak menjulukinya sebagai dukun oleh karena istilah "dukun" sering dikonotasikan negatif. Istilah "dukun" sering dipahami sebagai orang yang juga mampu melakukan guna-guna selain pengobatan. Dengan demikian orang ("pasien") tidak mau diduga kalau kedatangannya ke tempat pengobatan ada kaitannya dengan guna-guna. Sebaliknya juga dengan pengobat.

Dalam Ensiklopedi Sunda (2000: 203) sangat jelas digambarkan profil dari seorang dukun seperti berikut:

"Sebutan untuk orang yang melakukan pengobatan secara tradisional, seperti mengobati penyakit, termasuk kena teluh dan pelet, diganggu roh jahat. Selain dapat mengobati penyakit, dukun pun sering dimintai palakiah yang bersifat gaib untuk memperoleh kedudukan, pangkat, kekayaan, jodoh dll. Dalam melakukan pengobatan banyak cara yang dilakukan oleh dukun, dan kadang-

${ }^{8}$ Dukun, dalam KBBI (2013: 346), diartikan sebagai orang yang mengobati, menolong orang sakit, memberi jampi-jampi (mantra, guna-guna, dan sebagainya). kadang setiap dukun mempunyai cara pengobatan sendiri yang berbeda dari dukun lainnya. Ada yang menggunakan benda-benda tertentu, misalnya keris, cincin, tongkat, batu dan kemudian si pasien diberi minum air putih yang telah di-jampe terlebih dahulu; ada dukun yang memberi obat yang biasanya diramunya sendiri. Untuk menjadi seorang dukun diharuskan berguru terlebih dahulu dan harus menjalankan syarat-syarat tertentu, misalnya bertapa, berpuasa, mati geni, berendam di sungai, dsb., yang apabila syarat-syarat tersebut tak terpenuhi olehnya, maka gagallah untuk menjadi seorang dukun. Pada dasarnya dukun harus kuat pameulina. Meskipun tidak semua orang percaya terhadap dukun, tapi hingga sekarang, di kalangan orang Sunda masih banyak yang percaya kepada dukun dan meminta pertolongan kepadanya."

Cara pengobatan yang dilakukan oleh pengobat, tergolong pada pengobatan tradisional. Bahan, pembuatan obat, maupun cara pengobatan dilakukan berdasarkan pengetahuan yang telah diperoleh secara turun temurun dari pendahulunya. Bahan obat dan peralatan pengobatan didapat dari lingkungan sekitar, serta teknik pengobatan dilakukan secara sederhana dengan dibarengi doa-doa atau dijampe ${ }^{9}$. Tidak jarang, di mata orang awam, cara pengobatan yang dilakukan dianggap tidak logis.

Tidak ada diskriminasi gender untuk menjadi pengobat. Baik anak laki-laki

\footnotetext{
9 Jampe, dalam Ensiklopedi Sunda (Mustapa dkk., 2000: 310) diartikan sebagai mantra untuk menyembuhkan penyakit atau memberi sugesti agar si penderita sembuh atau berisi harapan-harapan untuk yang dijampe. (Lihat JANGJAWOKAN). Jampe bisa diucapkan oleh orang lain misalkan dukun, bisa juga diucapkan sendiri.
} 
maupun perempuan memiliki hak yang sama. Usiapun tidak membatasinya. Hanya saja untuk laki-laki yang berusia di bawah 40 tahun, tidak boleh menyapih atau melakukan pengobatan untuk menghentikan anak menetek dari ibunya. Sebabnya karena pada saat pengobatan, pengobat harus mengolesi puting si ibu dengan obat yang sudah diramunya. Dengan demikian pada pengobat yang masih muda dikhawatirkan tidak dapat menahan nafsu.

Selain itu, untuk menjadi pengobat juga tidak ada keterkaitan dengan jenjang pendidikan formal. Syarat untuk pengobat ini sama dengan pengobat tradisional di Kelurahan Ciganjur, DKI Jakarta. Dalam buku yang berjudul "Pengobatan Tradisional pada Masyarakat Betawi" (anonim, 1989: 98) dipaparkan sebagai berikut:

"untuk menjadi tenaga pengobat tradisional yang oleh masyarakat disebut "dukun", tidak pernah melalui suatu pendidikan khusus. Biasanya kemampuan seorang dukun diperoleh secara turun temurun diwariskan oleh karuhunnya. Atau ada juga memperoleh kemampuan "dukun" melalui wangsit yang didapat sebagai mimpi atau setelah untuk suatu waktu tertentu menjalankan puasa."

Ilmu apa saja yang sudah disampaikan oleh ayahnya sifatnya rahasia, demikian halnya dengan bahan-bahan obatnya. Kerahasiaan bahan obat lebih disebabkan adanya kekhawatiran ditiru oleh orang lain. Yang pasti, obat yang diramunya sendiri itu berbahan herbal dan dari bahan yang ada di lingkungan sekitar. Adapun untuk dapat menjadi pengobat, ada doa-doa dan keharusan melakukan puasa selama sepuluh hari berturut-turut .

Praktik pengobatan dibuka dari hari Senin sampai Minggu. Waktunya, dari pukul 08.00 - 16.00 WIB, dengan jam istirahat waktu salat dhuhur hingga pukul
13.00 WIB. Pada hari-hari biasa (di luar hari libur), pasien rata-rata berjumlah 8 orang. Sedangkan pada hari libur, seperti hari Sabtu, Minggu, atau hari libur nasional, jumlah pasien minimal 10 orang.

Tarif pengobatan tidak ditentukan besarannya. Dengan kata lain, besar kecilnya "upah" yang diberikan kepada pengobat bergantung keikhlasan "pasien". Ada yang memberikan "upah" sebesar lima puluh ribu rupiah dan sebagainya. Besar kecilnya "upah" ada keterkaitan dengan kemampuan ekonomi "pasien". "Pasien" yang mampu akan memberi "upah" lebih besar daripada "pasien yang kurang mampu.

Pasien bukan saja berasal dari Soreang, akan tetapi ada dari sekitaran Kabupaten Bandung seperti Kopo, Padalarang, Ciganitri dan sebagainya, ada dari Kota Bandung, dari luar kota, hingga luar Jawa. Mereka yang datang dari jauh biasanya bukan dengan sengaja datang, melainkan sekalian memiliki keperluan lain.

Tempat praktik pengobatan satu bangunan dengan tempat berjualan nasi, hanya saja beda ruangan. Warung nasi ada di ruangan bagian depan, sedangkan tempat praktik di ruangan belakang. Ruangan praktik dilengkapi dengan meja yang menempel pada papan yang menyekati ruangan, dilengkapi dengan bangku. Tidak heran apabila ruangannya lebih sesuai untuk ruang makan karena sebenarnya memang diperuntukkan mereka yang makan di sana, yang kehabisan bangku di ruangan depan.

Dari ruangan pengobatan, "pasien" dibawa ke bangunan di seberangnya alias toko mainan. Maksudnya, manakala anak rewel karena takut, bingung, atau tidak mau diobati, ia diiming-imingi untuk dibelikan mainan terlebih dahulu agar selanjutnya mau diobati. Di toko ini tersedia mainan baik untuk anak laki-laki maupun anak perempuan. Harga mainan yang dijual relatif terjangkau oleh semua kalangan. 
Awal mulainya pengobatan oleh Abah hingga sekarang oleh si Ibu (puteranya), lokasi tidak berpindah-pindah dan tempat (bangunannya) pun nyaris tidak mengalami perubahan. Tidak heran apabila "pasien" baru pun akan dengan mudah menemukan tempat tersebut karena orangorang di sana (di pasar) akan dapat menjadi penunjuknya.

\section{Alasan Pengobatan}

Alur seorang "pasien" sampai datang ke pengobat tradisional pada kenyataannya tidak berbeda antara seseorang dengan orang lainnya, apapun jenis keluhannya. Alur ini seperti yang tergambarkan dalam Teori Aksi dari Talcott Parsons. ${ }^{10}$

Berikut gambaran alur alasan seseorang melakukan pengobatan :

\section{Masalah (Kebiasaan Buruk)}

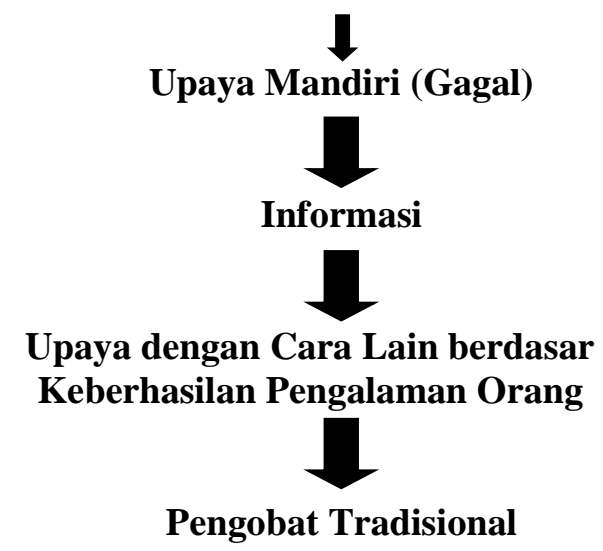

Sumber: Ria Intani

Adapun bagi mereka yang telah berpengalaman dengan masalah serupa, entah itu dialami pada anak-anak yang

\footnotetext{
${ }^{10}$ Teori Aksi dari Talcott Parsons menjelaskan bahwa seorang individu tak mungkin lepas dari ikatan-ikatan struktur sosial di mana ia berada. Namun demikian seorang individu memiliki kemampuan untuk memilih berbagai alternatif tindakan secara aktif, kreatif, dan evaluatif yang memungkinkan tercapainya tujuan khas yang ia inginkan (Bungin, 2009: 35).
}

terlahir sebelumnya, pada adiknya, pada saudaranya dan sebagainya, tidak akan lagi berpikir panjang manakala mendapatkan masalah serupa lagi. Mereka akan langsung mendatangi pengobat yang telah berhasil mengatasi masalah yang pernah mereka, saudara, atau orang lain alami. Berikut gambaran alurnya:

\section{Masalah (Kebiasaan Buruk)

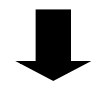

\section{Pengalaman Keberhasilan Masa Lalu

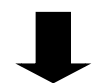

Pengobat

Sumber: Ria Intani

\section{Tata Cara Pengobatan}

Pengobatan yang banyak dilakukan adalah kebiasaan menghisap jari dan ketergantungan pada dot dan Asi, dan anak yang selalu menempel pada ibunya. Menyembuhkan ketergantungan, baik itu pada Asi juga dot, dikenal dengan istilah nyapih/ morotl mesat ${ }^{11}$ (dalam bahasa Sunda). Terkait dengan istilah tersebut, tidak heran apabila tamu yang datang ke tempat pengobatan sambil membawa anak, mereka akan langsung ditanya: "bade morot?" (akan nyapih?). Atau, kalaupun tidak bertanya pada tamu apa tujuannya datang ke sana, anak si pengobat atau pekerja yang ada di warung secara spontan akan "teriak": "Mak, morot!" (Mak, nyapih!).

Pengobatan baik untuk menghisap jari dan ketergantungan pada Asi, dot, dan ibunya, serupa dalam hal obatnya, demikian pula hampir serupa dalam hal tata cara pengobatannya.

Obatnya berupa sepiring nasi dengan lauk abon dan air putih yang telah didoai/ dijampe di depan anak yang "bermasalah". Pilihan pada nasi abon sebagai media semata-mata karena abon

11 Mesat berarti menarik (Surayin \& E. Kosasih, 2006: 124). 
secara umum disukai oleh anak-anak. Selain itu ada obat luar untuk dioleskan. Obatnya berwarna hitam, menyerupai krem dengan kekentalannya sedikit lebih kental dari lem. Obat ditempatkan dalam sebuah wadah menyerupai kaleng atau tabung. Alat olesnya berupa sepotong kayu kecil yang pada bagian ujungnya diberi guntingan sejenis imitasi kulit berwarna hitam yang diikatkan pada kayu tersebut hingga bentuknya menyerupai sapu.

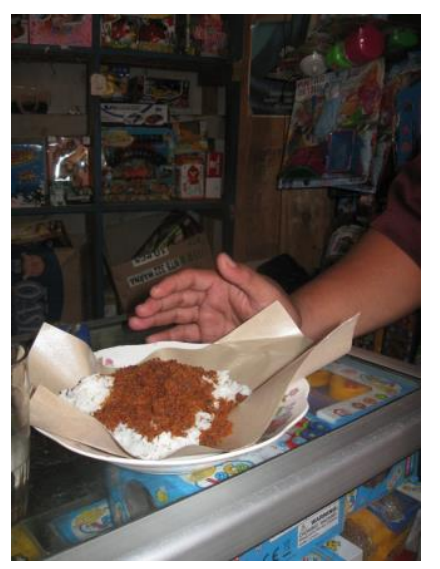

Gambar 1. Nasi Abon Sumber: Ria Intani

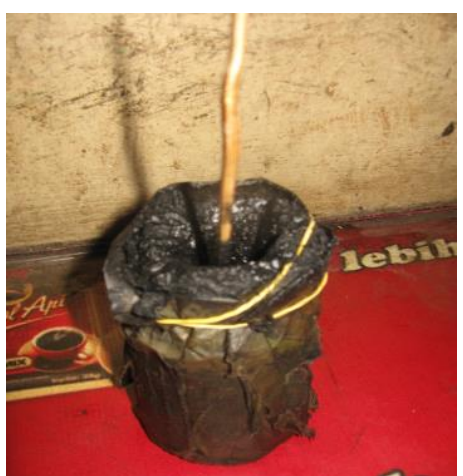

Gambar 2. Obat Oles Sumber: Ria Intani

Tahapan pengobatan untuk kebiasaan menghisap jari sebagai berikut: Tamu ditanya apa yang menjadi keluhannya serta ditanya nama dan usia anak yang "bermasalah" - sepiring nasi abon dan air putih yang didoai/ dijampe di depan anak yang "bermasalah" - anak diberi minum air putih dan disuapi nasi abon oleh ibunya atau oleh orang lain yang membawanya ke tempat pengobatan, minimal dua suapan - jari anak diolesi dengan obat sambil ditakut-takuti: "hiii...jijik ada cacing, jangan mut 'menghisap' jari lagi ya”.

Berikut gambaran alur pengobatan pada anak yang memiliki kebiasaan menghisap jari:

\section{Permasalahan, Nama dan Usia Anak

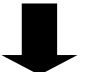 \\ Nasi Abon dan Air Putih Didoa'i/ Dijampe

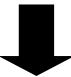 \\ Anak Diberi Minum Air Putih

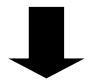 \\ Anak Disuapi Nasi Abon \\ Jari Anak Diolesi Obat}

Sumber: Ria Intani

Tahapan pengobatan untuk ketergantungan pada dot sebagai berikut: Tamu ditanya apa yang menjadi keluhannya serta ditanya nama dan usia anak yang "bermasalah" - sepiring nasi abon dan air putih yang didoai/ dijampe di depan anak yang "bermasalah" - anak diberi minum air putih dan disuapi nasi abon oleh ibu atau orang lain yang membawanya ke tempat pengobatan, minimal dua suapan - dot yang sehari-hari digunakan anak diolesi obat sambil anak ditakut-takuti: "hiii...jijik ada cacing di dotnya....buang ya...nanti minum pakai gelas saja ya" - dot dibuang ke tempat khusus pembuangan dot.

Berikut gambaran alur pengobatan pada anak yang memiliki ketergantungan minum susu dengan dot:

\section{Permasalahan, Nama dan Usia Anak}

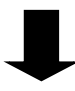




\section{Nasi Abon dan Air Putih Didoa'i/ Dijampe

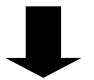

Anak Diberi Minum Air Putih

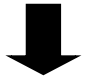

Anak Disuapi Nasi Abon

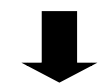

Dot Diolesi Obat

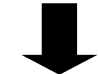

Dot Dibuang

Sumber: Ria Intani

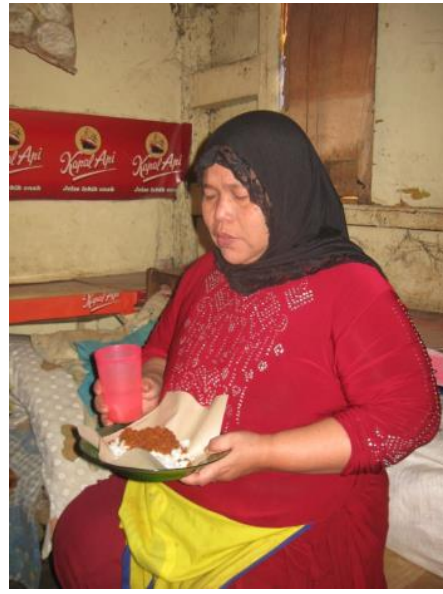

Gambar 3. Pengobat mendo'ai/ menjampe nasi abon dan air putih.

Sumber: Ria Intani

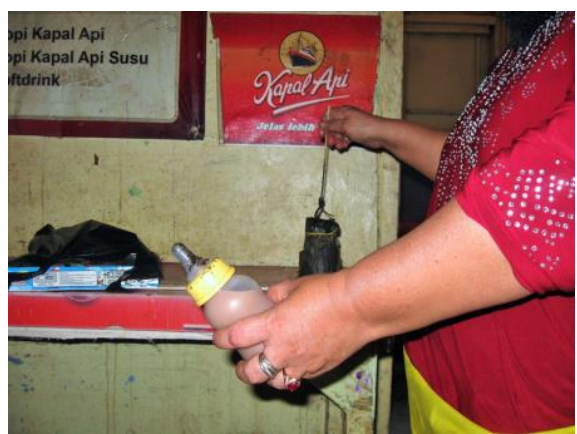

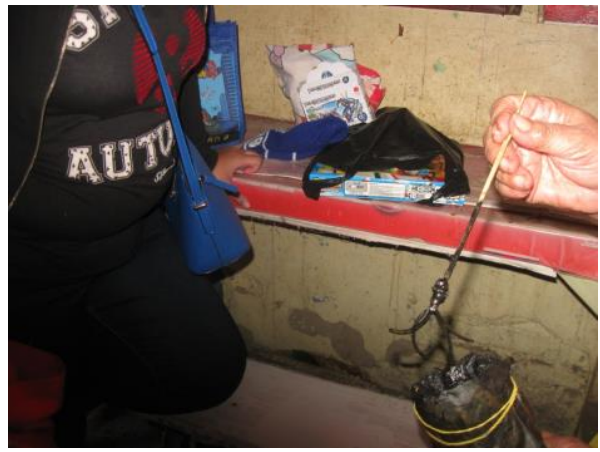

Gambar 4. Dot Dioles Obat Sumber: Ria Intani

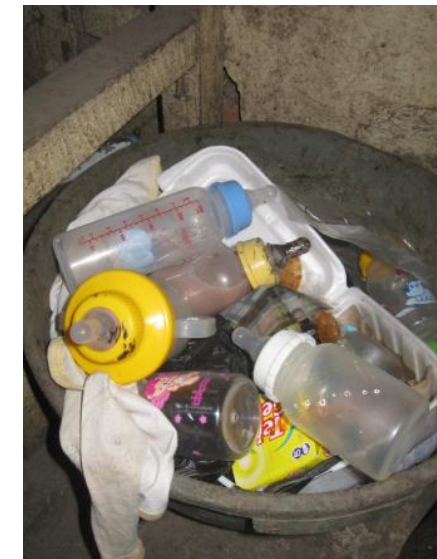

Gambar 5. Wadah Pembuangan Dot Sumber: Ria Intani

Tahapan pengobatan untuk ketergantungan pada Asi sebagai berikut: Tamu ditanya apa yang menjadi keluhannya serta ditanya nama dan usia anak yang "bermasalah" - sepiring nasi abon dan air putih yang didoai/ dijampe di depan anak yang "bermasalah" - anak diberi minum air putih dan disuapi nasi abon oleh ibunya minimal dua suapan puting si ibu diolesi obat sambil si pengobat berkata pada anak yang "bermasalah": "hiii...jijik ada cacing...jangan enen/ nenen lagi ya...nanti minum pakai gelas saja".

Berikut gambaran alur pengobatan pada anak yang tidak mau berhenti menetek:

Permasalahan, Nama dan Usia Anak 


\section{L \\ Nasi Abon dan Air Putih Didoa'i/ \\ Dijampe

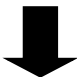 \\ Anak Diberi Minum Air Putih

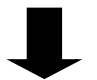 \\ Anak Disuapi Nasi Abon

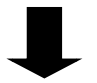 \\ Puting Ibunya Diolesi Obat}

Sumber: Ria Intani

Tahapan pengobatan untuk anak yang selalu menempel pada ibunya atau "tidak mau" sama orang lain sebagai berikut: Tamu ditanya apa yang menjadi keluhannya serta ditanya nama dan usia anak yang "bermasalah" - sepiring nasi abon dan air putih yang didoai/ dijampe di depan anak yang "bermasalah" - anak diberi minum air putih dan disuapi nasi abon oleh neneknya atau orang lain yang membawanya ke tempat pengobatan, minimal dua suapan - kepala anak diusapusap oleh si pengobat sambil didoai lalu dikatakan: "sama nenek aja ya sekarang...ibunya mau kerja".

Berikut gambaran alur pengobatan pada anak yang memiliki ketergantungan pada ibunya:

Permasalahan, Nama dan Usia anak

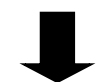

Nasi Abon dan Air Putih Didoa'i/ Dijampe

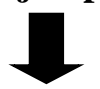

Anak Diberi Minum Air Putih

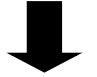

Anak Disuapi Nasi Abon

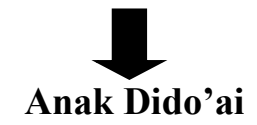

Sumber: Ria Intani

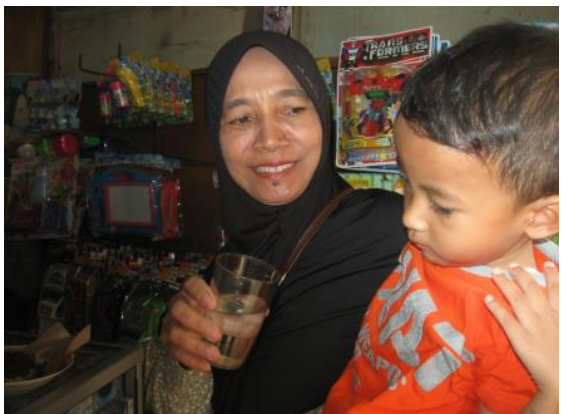

Gambar 6. Nenek meminumkan air do'a/ air jampe pada cucunya. Sumber: Ria Intani

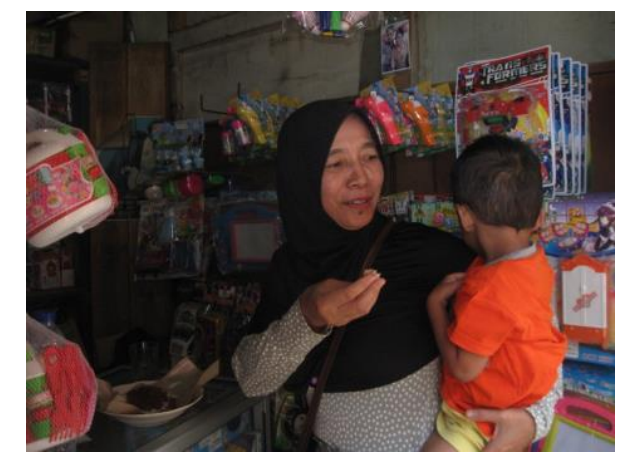

Gambar 7. Nenek menyuapkan nasi abon pada cucunya.

Sumber: Ria Intani

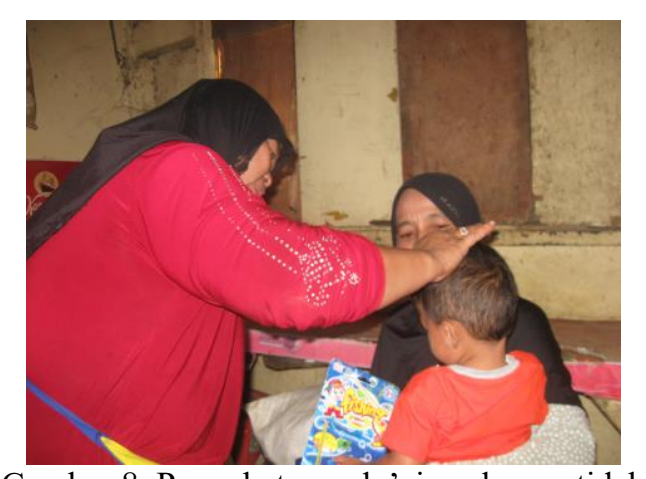

Gambar 8. Pengobat mendo'ai anak agar tidak lagi menempel pada ibunya.

Sumber: Ria Intani

Menurut penuturan pengobat, nyaris tidak ada "pasien" yang kembali lagi. Dalam arti, pada umumnya "pasien" sekali berobat langsung sembuh atau hilang kebiasaan buruknya. Satu dua orang "pasien" yang datang lagi, mereka bukan belum sembuh atau hilang kebiasaan buruknya, melainkan karena masih rewel atau ada kebiasaan "aneh". Kerewelan anak biasanya berupa tangisan di malam 
hari, namun tanpa mengeluarkan air mata. Atau,kebiasaan "anehnya" adalah anak selalu ingin keluar rumah.

Rewel atau kebiasaan "aneh" tadi biasanya terjadi pada anak yang masih di bawah usia 2 tahun. Baik itu terjadi pada anak yang ada ketergantungan pada dot, Asi, ketergantungan pada ibunya, atau yang memiliki kebiasaan menghisap jari. Konon hal itu bisa terjadi karena anak disapih sebelum waktunya (sebelum usia 2 tahun). Anak dengan usia di bawah 2 tahun masih dianggap wajar apabila memiliki kebiasaan seperti yang tersebut di atas. Penyapihan yang dipaksakan tadi, terkecuali untuk kebiasaan menghisap jari dan menggunakan dot, biasanya dialami anak yang ibunya akan bekerja di luar rumah.

Apabila terjadi anak rewel, biasanya anak dibawa lagi ke tempat pengobatan untuk "diobati". Anak diberi minum air putih yang sudah didoa'i. Kadangkala air doa tersebut sudah dimintakan dari awal manakala melakukan pengobatan yang pertama. Maksudnya sebagai persiapan apabila anak rewel.

\section{PENUTUP}

Sekecil apa pun, logis tidak logis, pengobat yang telah berhasil menangani kebiasaan buruk anak-anak, telah memberi manfaat bagi dunia kesehatan.

Kebiasaan buruk pada anak dengan menghisap jari, bergantung pada dot dan Asi, secara tidak langsung akan berdampak pada terganggunya kesehatan anak. Ketergantungan pada Asi menyebabkan anak "menolak" menyantap makanan lain padahal vitamin yang dibutuhkan oleh tubuh seorang anak tidak melulu dari Asi. Selanjutnya, anak yang selalu menempel pada ibunya, ia akan sulit mandiri dan bersosialisasi dengan orang lain.

Keberhasilan pengobatan dari orang per orang yang kemudian tersebar dari mulut ke mulut menjadi promosi tentang pengobatan itu sendiri. Keberhasilan dari orang per orang jugalah yang kemudian menggiring orang memiliki pilihan lain untuk menyembuhkan kebiasaan buruk anak.

Kebiasaan buruk pada anak, apakah itu menghisap jari, ketergantungan pada dot, Asi, dan ibunya menjadi hilang melalui "obat" yang diciptakan oleh si pengobat. Hal ini sebagaimana definisi obat untuk mengurangi, menghilangkan, menyembuhkan penyakit.

Selain obatnya berupa doa/ jampe, juga obat oles. Obat yang dioleskan termasuk obat kampung atau obat tradisional seperti didefinisikan dalam KBBI karena terbuat dari tumbuhtumbuhan dan sebagainya yang diramu sendiri (bukan dari apotek atau dari pabrik farmasi). Obat tersebut juga termasuk obat luar karena penggunaannya dioleskan, bukan diminum atau ditelan.

Apabila melihat dari kondisi pasien yang datang, mereka menempuh pengobatan dengan datang ke pengobat (tradisional) bukan karena rumah pasien jauh dari fasilitas kesehatan atau di daerahnya tidak terdapat tanaman obat atau mereka secara ekonomi kurang mampu. Keputusan menempuh cara pengobatan ini karena mereka dihadapkan pada pilihan beragam cara, pada situasi dan kondisi (pernah gagal dengan upaya mandiri, melihat keberhasilan pengalaman orang lain), dan ada ide-ide berupa informasi, masukan, yang muncul di lingkungan sosialnya.

Keputusan/ sikap yang diambil oleh "pasien" untuk menempuh pengobatan ini sesuai dengan pendapat Parsons dalam Teori Aksinya, bahwa:

- "Pasien" sebagai individu yang aktif.

- "Pasien" memiliki tujuan yang ingin dicapai.

- "Pasien" dihadapkan pada pilihan beragam cara yang dapat ditempuh untuk mencapai tujuan.

- Terdapat beragam kondisi dan situasi yang bisa memengaruhi "pasien" dalam memilih cara untuk mencapai tujuan.

- Penentuan tujuan yang diinginkan dan cara untuk mencapainya, berpedoman pada ide-ide tertentu yang ada dalam 
lingkungan sosial di mana "pasien" berada.

- Tindakan ataupun pengambilan keputusan untuk bertindak dengan cara tertentu, merupakan hasil dari pertimbangan "pasien" atas segala sistem situasi yang ia hadapi (nilai, norma, kondisi, dan situasi).

Apabila dibuatkan bagannya maka alur keputusan pasien melakukan pengobatan tradisional berlangsung seperti tahapan berikut:

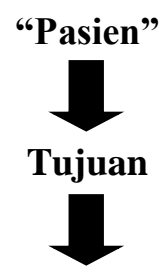

Pilihan pada Beragam Cara

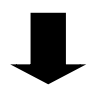

Kondisi/ Situasi Memengaruhi "Pasien"

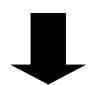

Penentuan Tujuan Berpedoman pada Nilai/ Norma/ Ide-ide di Lingkungan Sosial

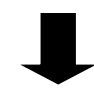

Keputusan merupakan Hasil Pertimbangan atas Dasar Situasi yang Dihadapi

Sehubungan dengan hal tersebut, sudah selayaknya pula pengobat yang bersangkutan, termasuk dengan tata cara pengobatannya, harus tercatat sebagai salah satu kekayaan budaya (tradisional) bangsa.

\section{DAFTAR SUMBER}

\section{Buku}

Anonim. 1991

$\begin{array}{lcr}\text { Pengobatan } & \text { Tradisional } & \text { pada } \\ \text { Masyarakat } & \text { Betawi di } & \text { Kelurahan } \\ \text { Ciganjur. } & \text { Depdikbud: } & \text { Dirjen } \\ \text { Kebudayaan, } & \text { Direktorat } & \text { Jarahnitra, }\end{array}$

Proyek Inventarisasi dan Pembinaan Nilai-nilai Budaya.

Bungin, H. M. Burhan. 2009.

Penelitian Kualitatif. Jakarta: Prenada Media Group.

Mustapa, A., Abdurrachman, Ace Hasan Sueb, Ajip Rosidi, S. M. Ardan. 2000. Ensiklopedi Sunda: Alam, Manusia, dan Budaya. Bandung: Pustaka Jaya.

Saebani, Beni Ahmad. 2012. PengantarAntropologi. Bandung: CV Pustaka Setia.

Surayin \& E. Kosasih. 2006. Kamus Basa Sunda. Bandung: Yrama Widya.

Tim Redaksi KBBI. 2012.

Kamus Besar Bahasa Indonesia Pusat Bahasa Depdiknas Edisi Keempat. Jakarta: PT Gramedia Pustaka Utama.

\section{Jurnal/ Skripsi}

Dermawan, Rahmat. "Peran Battra dalam Pengobatan Tradisional pada Komunitas Dayak Agabag di Kecamatan Lumbis Kabupaten Nunukan" dalam eJournal Sosiologi Konsentrasi, Volume 1, Nomor 4, 2013: 50-61.

Wirata, I Wayan. "Hegemoni Pemerintah dan Resistensi Wetu Telu Suku Sasak di Kecamatan Bayan Kabupaten Lombok Utara" dalam Jurnal Penelitian Sejarah dan Nilai Tradisional, Volume 20, Nomor 1, 2012: 75-83.

Yasin, Irwandhy Kusuma. 2013.

Perlindungan Konsumen terhadap Testimoni Iklan Pengobatan Tradisional Herbal dan Akupuntur. Skripsi. Makassar: Bagian Hukum Keperdataan Fakultas Hukum Universitas Hasanuddin.

\section{Internet}

https://id.wikipedia.org/wiki/Soreang,_Bandun $g$, Soreang, Bandung. Diakses 19 Agustus 2015, pukul 14.26 WIB.

http:/www.wishingbaby.com/manfaat-asieksklusif/. Manfaat Asi Eksklusif oleh Wishingbaby. Diakses 22 Agustus 2015, pukul 19.33 WIB.

http://www.dw.com/id/10-fakta-ajaib-air-susuibu/a-17830417. 10 Fakta Ajaib Air Susu 
Ibu. Diakses 22 Agustus 2015, pukul 19.40 WIB.

http://www.tanyadok.com/anak/dot-atauempeng-bergunakah-untuk-bayi. Dot atau Empeng, Bergunakah untuk Bayi? Diakses 22 Agustus 2015, pukul 20.10.

http://nutrisianaksehat.blogspot.com/2015/05/c ara-agar-anak-berhenti-ngempengngedot.html. Cara Anak Agar Berhenti Ngempeng-Ngedot. Diakses 22 Agustus 2015, pukul 20.45

http://www.tanyadok.com/anak/dot-atauempeng-bergunakah-untuk-bayi. Diakses 22 Agustus 2015 pukul 20.10 WIB.

https://ireinenorma.wordpress.com/about/.

Kebiasaan Buruk pada Anak. Diakses 22 Agustus 2015 pukul 20.30 WIB. 